Article

\title{
Determination of the Extraction, Physicochemical Characterization, and Digestibility of Sulfated Polysaccharides in Seaweed-Porphyra haitanensis
}

\author{
Mingshuang Dong, Yanhui Jiang, Chun Wang, Qian Yang, Xiaolu Jiang and Changliang Zhu * \\ College of Food Science and Engineering, Ocean University of China, 5 Yushan Road, Qingdao 266003, China; \\ MingsDong@163.com (M.D.); jiangyanhui@ouc.edu.cn (Y.J.); wangchun_95@163.com (C.W.); \\ 21190711078@stu.ouc.edu.cn (Q.Y.); jiangxl@ouc.edu.cn (X.J.) \\ * Correspondence: chlzhu@163.com; Tel.: +86-15165252650
}

Received: 12 October 2020; Accepted: 26 October 2020; Published: 28 October 2020

\begin{abstract}
The aim of the study was to extract Porphyra haitanensis polysaccharides (PHPs) using the water extraction and alcohol precipitation methods and explore their antioxidant activity and physicochemical properties. The single-factor and Box-Behnken response surface methodologies were used to optimize the extraction of polysaccharides from Porphyra haitanensis. Our results showed that the polysaccharide yield was as high as $20.48 \%$ with a raw material to water ratio of 0.04 , and extraction time of $3 \mathrm{~h}$ at $80^{\circ} \mathrm{C}$. The extraction rate observed was similar to the actual extraction rate, thus proving the reliability of the optimization model. The extracted polysaccharides primarily consisted of galactose, glucose, and fucose in the molar ratio 76.2:2.1:1, respectively. The high performance gel permeation chromatography (HPGPC) results showed that the molecular weight of the PHPs obtained was $6.3 \times 10^{5} \mathrm{Da}$, and the sulfate content was $2.7 \mathrm{mg} / \mathrm{mL}$. Fourier infrared spectroscopy was used to analyze the functional groups and structures of the polysaccharides. The effect of concentration, temperature, and $\mathrm{pH}$ on the apparent viscosity of the PHPs solution were studied using rheology experiments, which revealed that PHPs were a "non-Newtonian fluid" with shear-thinning behavior. The viscosity of the PHPs gradually increased with increasing sugar concentration, and decreased with increasing temperature, acidity, and alkalinity. Detection of the antioxidant activity of $\mathrm{OH}^{*}$, $\mathrm{DPPH}^{*}$, and ABTS* revealed that the scavenging activity of ABTS* was higher than that $\mathrm{OH}^{*} \mathrm{OH}^{*}$ and $\mathrm{DPPH}^{*}$ in the concentration range of $1-5 \mathrm{mg} / \mathrm{mL}$. In the experiments of simulating gastric juice and alpha amylase in vitro, it was found that PHPs can better resist digestion of alpha amylase, and have better resistance than fructooligosaccharide (FOS), so PHPs have potential prebiotic activity. These findings demonstrate the potential of PHPs for use in the food and cosmetic industries.
\end{abstract}

Keywords: Porphyra haitanensis polysaccharides; physicochemical characterization; vitro digestibility

\section{Introduction}

Porphyra, a seaweed belonging to the Division Rhodophyta and Family Bangiaacea, is widely distributed in the intertidal waters between the cold and subtropical zones [1]. Porphyra haitanensis is one of the most economical seaweeds cultivated in China [2]; it is made up of proteins, sulfated polysaccharides, amino acids, and minerals. Sulfated polysaccharides, one of the primary active ingredients [3] in Porphyra, are made up of disaccharide units of alternating 3-linked $\beta$-d-galactosyl residues and 4-linked $\alpha$-l-galactosyl residues, in addition to few 6-sulfate residues.

Recently, seaweed polysaccharides have gained importance owing to their antiviral, antioxidant, and antitumor activities [4,5]. Porphyra haitanensis polysaccharide (PHP) has attracted much attention owing to its composition, which endows it with antioxidant [6], antitumor [7], hypolipidemic [8], 
and antiviral [9] properties and other bioactivities. Zhang et al., [10] prepared a sulfated variant of the Porphyra polysaccharide and found that its antioxidant activity was significantly enhanced compared to that of the unmodified Porphyra polysaccharide. Additionally, Zhang [11] also proved that Porphyra polysaccharides act as scavengers of free radicals and antioxidants, thereby playing an important role in preventing oxidative damage in organisms. Moreover, sulfated polysaccharides of different molecular weights exhibit different antioxidant activities, the lower the molecular weight, the better the antioxidant activity [12]. Guiping Gong et al. [13] performed water extraction and alcohol precipitation (temperature: $80{ }^{\circ} \mathrm{C}$, raw material to water ratio: 1:20 (w/v), and time: $1.5 \mathrm{~h}$ ) and obtained a Porphyra yield of $3.8 \%$, while Bilal Muhammad Khan [14] used a temperature of $90{ }^{\circ} \mathrm{C}$, raw material to water ratio of 1:30 (w/v), and extraction time of $3 \mathrm{~h}$, and obtained a yield of $3.3 \%$ Porphyra. Additionally, the viscosity of the polysaccharides obtained affect their rheological properties, polysaccharides can be used as excipients in new drug delivery systems [15] and as stabilizers for oil-in-water systems in emulsions [16], which is crucial for understanding the structure and potential functions of the polysaccharides. The relationship between intestinal microecological flora and human health has attracted more and more attention, which has led to an increase in the demand for prebiotics. The experiments have shown that undigested plant polysaccharides have excellent prebiotic activities, such as rapeseed polysaccharides [17], Chimonobambusa quadrangularis polysaccharides, and those in seaweeds like Himathalia elongata and Gigartina pistillata [18]. However, the rheological properties and in vitro simulated digestion studies are scarce for Porphyra polysaccharides.

In this study, water extraction and alcohol precipitation methods were used to optimize the extraction of polysaccharides from Porphyra haitanensis. Based on the response index of the PHPs, the extraction process was optimized using the response surface methodology. The scavenging ability of $\mathrm{OH}^{*}$ free radicals, $\mathrm{DPPH}^{*}$, and ABTS* was measured and analyzed to characterize their antioxidant capacity. Additionally, the rheological properties and in vitro digestibility of the PHPs were also studied. The purpose of this study was to provide a theoretical basis for the development and utilization of Porphyra haitanensis.

\section{Results and Discussion}

\subsection{Single-Factor Experiments for the Extraction of Porphyra Polysaccharides}

\subsubsection{Effect of Extraction Temperature on the Yield of Polysaccharides}

Extraction was performed at different temperatures $\left(70,80,90\right.$, and $\left.100^{\circ} \mathrm{C}\right)$, keeping the extraction time and raw material to water ratio constant at $2 \mathrm{~h}$ and $1 / 25 \mathrm{~g} / \mathrm{mL}$, respectively. Generally, the solubility of polysaccharides increases with increasing temperature. Moreover, high temperature promotes the diffusion of polysaccharides from the cells [19]. As shown in the Figure 1a, at first the extraction rate increased and subsequently decreased with increasing temperature. However, no significant difference was observed between the extraction rates at $80^{\circ} \mathrm{C}$ and $90^{\circ} \mathrm{C}$, since the polysaccharide structure is destroyed at very high temperatures, leading to their degradation. Therefore, $80^{\circ} \mathrm{C}$ was chosen as the optimum temperature. 

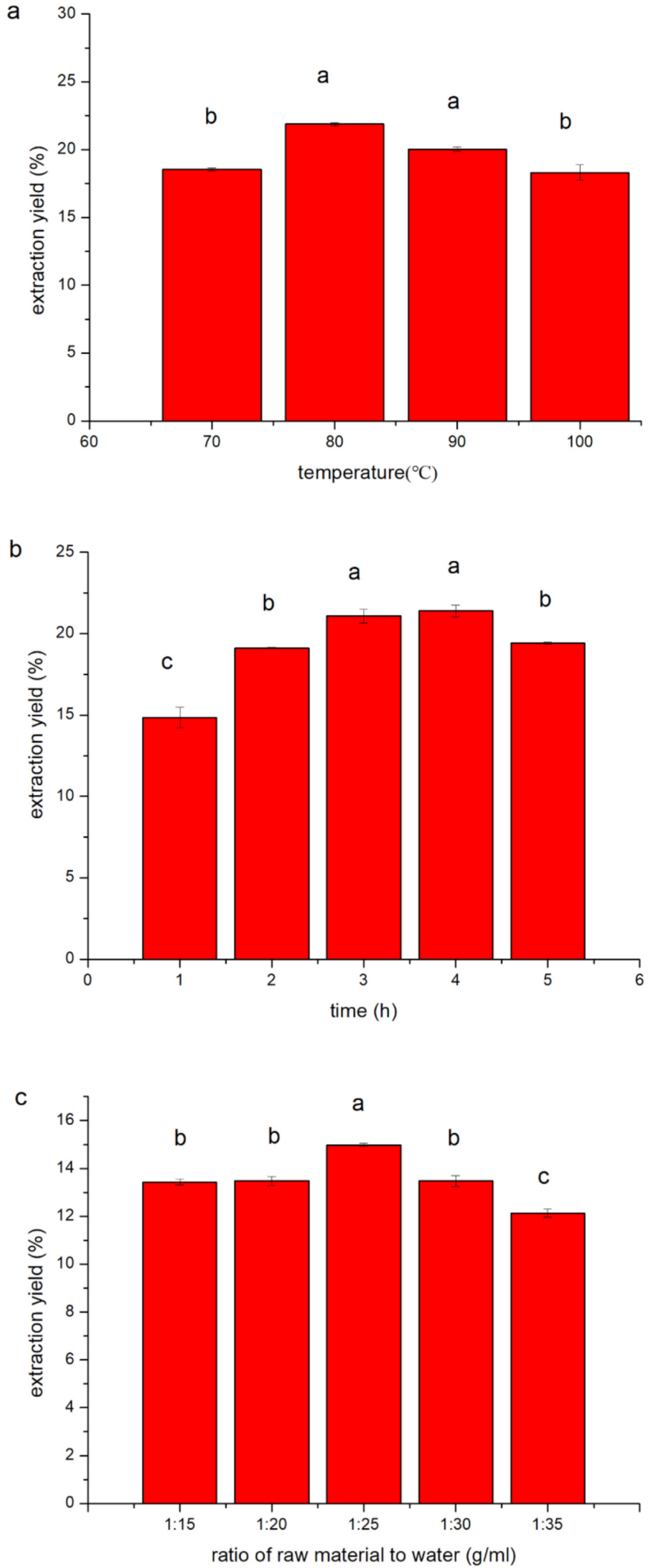

Figure 1. Effects of different factors on the yield of Porphyra haitanensis polysaccharides (PHPs). (a) Extraction temperature, (b) extraction time, (c) ratio of raw material to water. Data are means $\pm \mathrm{SD}$ $(n=3)$, the error bars represent the standard deviation, values marked by the same letter are not significantly different $(p<0.05)$. 


\subsubsection{Effect of Extraction Time on the Yield of Polysaccharides}

Extraction was performed using different extraction times of $1,2,3,4$, and $5 \mathrm{~h}$. The temperature was $80^{\circ} \mathrm{C}$, and the raw material to water ratio was $1 / 25 \mathrm{~g} / \mathrm{mL}$. As shown in the Figure $1 \mathrm{~b}$, the extraction rate first increased and subsequently decreased. The extraction rate at $3 \mathrm{~h}$ and $4 \mathrm{~h}$ was $21.087 \%$ and $21.400 \%$, respectively. No significant difference was observed between the extraction rates at 3 and $4 \mathrm{~h}$. Excess extraction time leads to polysaccharide degradation [20], and thus $3 \mathrm{~h}$ was chosen as the optimum time.

\subsubsection{Effect of the Raw Material to Water Ratio on the Yield of Polysaccharides}

Different raw material to water ratios of $1 / 15,1 / 20,1 / 25,1 / 30$, and $1 / 35 \mathrm{~g} / \mathrm{mL}$ were tested, keeping the extraction time and temperature constant at $2 \mathrm{~h}$ and $80^{\circ} \mathrm{C}$, respectively. As shown in Figure $1 \mathrm{c}$, as the raw material to water ratio increased from $1 / 15$ to $1 / 20 \mathrm{~g} / \mathrm{mL}$, the extraction rate decreased from $13.432 \%$ to $13.477 \%$, respectively. However, when the raw material to water ratio was continuously increased to $1 / 25$ and $1 / 35 \mathrm{~g} / \mathrm{mL}$, the yield decreased from $14.982 \%$ to $12.132 \%$, respectively, since a high raw material to water ratio reduces the concentration and viscosity of the extraction solvent, thereby facilitating the dissolution of polysaccharide molecules in the water. Through this experiment, $1 / 25 \mathrm{~g} / \mathrm{mL}$ was chosen as the optimum raw material to water ratio.

\subsection{Optimization of Polysaccharide Extraction}

The Box-Behnken design for response surface methodology was used to optimize the technological conditions in the water extraction process of PHPs. The primary aim of RSM was to efficiently identify the optimum values of independent variables to maximize responses [21]. Based on the aforementioned single-factor experiments, the raw material to water ratio (A), extraction time (B), and extraction temperature $(C)$ were the independent variables, and the polysaccharide yield $(\mathrm{Y})$ was the response value. A three-factor and three-level Box-Behnken design was applied to the surface optimization experiment. The central experiment point was repeated in three groups. The experimental data and processing are shown in Table 1, the experimental data were analyzed by performing multiple regression, and a second-order polynomial equation was obtained to describe the relationship between the variable and the response value:

$$
\begin{gathered}
\mathrm{Y}=20.33-0.19 \mathrm{~A}+0.17 \mathrm{~B}+0.87 \mathrm{C}-0.24 \mathrm{AB}-0.61 \mathrm{AC}-0.10 \mathrm{BC}-1.25 \mathrm{~A}^{2}-2.08 \mathrm{~B}^{2}-1.58 \mathrm{C}^{2} \\
\left(\mathrm{R}^{2}=0.9563\right)
\end{gathered}
$$

Table 1. Box-Behnken test design and response values.

\begin{tabular}{ccccc}
\hline Number & $\mathbf{A} /(\mathrm{g} / \mathbf{m L})$ & $\mathbf{B} / \mathbf{h}$ & $\mathbf{C} /{ }^{\circ} \mathbf{C}$ & $\mathbf{Y} / \%$ \\
\hline 1 & 0.05 & 3.00 & 90.00 & 17.79 \\
2 & 0.03 & 4.00 & 80.00 & 17.45 \\
3 & 0.04 & 4.00 & 90.00 & 17.24 \\
4 & 0.04 & 3.00 & 80.00 & 20.05 \\
5 & 0.05 & 2.00 & 80.00 & 17.05 \\
6 & 0.03 & 3.00 & 70.00 & 16.01 \\
7 & 0.04 & 2.00 & 70.00 & 15.9 \\
8 & 0.04 & 2.00 & 90.00 & 17.1 \\
9 & 0.04 & 3.00 & 80.00 & 20.79 \\
10 & 0.04 & 3.00 & 80.00 & 20.15 \\
11 & 0.03 & 3.00 & 90.00 & 19.69 \\
12 & 0.05 & 4.00 & 80.00 & 16.91 \\
13 & 0.05 & 3.00 & 70.00 & 16.53 \\
14 & 0.04 & 4.00 & 70.00 & 16.45 \\
15 & 0.03 & 2.00 & 80.00 & 16.61 \\
\hline
\end{tabular}


Pareto analysis of variance (ANOVA) was also used to analyze the significance of the developed model equation. The obtained results showed that the developed model had acceptable $\mathrm{F}$ value, $p$ value, correlation coefficient $\left(\mathrm{R}^{2}\right)$, and adj- $\mathrm{R}^{2}$ values [22]. It can be seen from Table 2 that the selected model was highly significant $(p<0.0001)$. The $p$ value of lack of fit was $0.2840(p<0.05)$, which is not significant; also, the difference between the model and the experimental value was small. The correlation coefficient was $0.9563(p>0.9)$, indicating that the model fits well. The value of adj- $\mathrm{R}^{2}$ was 0.8776 , indicating that the model explains $87.76 \%$ of the change in the response value. In summary, the regression model had a good fit, showed small test errors, and could accurately analyze and predict the yield of the PHP extraction process.

Table 2. Multivariate regression equation fitting for analysis of variance.

\begin{tabular}{cccccc}
\hline Source & Sum of Squares & df & Mean Square & $\boldsymbol{F}$ Value & $p$ Value \\
\hline model & 35.32 & 9 & 3.92 & 12.15 & 0.0067 \\
A & 0.27 & 1 & 0.27 & 0.85 & 0.3995 \\
B & 0.24 & 1 & 0.24 & 0.75 & 0.4267 \\
C & 6.00 & 1 & 6.00 & 18.59 & 0.0076 \\
AB & 0.24 & 1 & 0.24 & 0.74 & 0.4280 \\
AC & 1.46 & 1 & 1.46 & 4.53 & 0.0865 \\
BC & 0.042 & 1 & 0.042 & 0.13 & 0.7331 \\
$\mathrm{~A}^{2}$ & 5.73 & 1 & 5.73 & 17.75 & 0.0084 \\
$\mathrm{~B}^{2}$ & 15.96 & 1 & 15.96 & 49.40 & 0.0009 \\
$\mathrm{C}^{2}$ & 9.20 & 1 & 9.20 & 28.49 & 0.0031 \\
Residual & 1.62 & 5 & 0.32 & & \\
Lack of Fit & 1.29 & 3 & 0.43 & 2.67 & 0.2840 \\
Pure error & 0.32 & 2 & 0.16 & & \\
Cor total & 36.93 & 14 & & & \\
\hline
\end{tabular}

Note: $p<0.05$, significant difference; $p<0.01$, the difference is very significant.

It can also be seen from the $\mathrm{F}$ and $p$ values in Table 2 that temperature has the greatest effect on the extraction yield of PHPs, followed by time and raw material to water ratio. The items $B C, A C, A B$, $\mathrm{B}$, and $\mathrm{A}$ have no significant effect $(p>0.05)$. However, the effects of the other items were significant $(p<0.05)$. Among these, $\mathrm{A}^{2}, \mathrm{~B}^{2}, \mathrm{C}^{2}$, and $\mathrm{C}$ are extremely significant $(p<0.01)$. Therefore, a simple linear relationship does not exist between the experimental factors and the response value.

\subsection{Analysis of the Interaction Effects between Two Factors}

The design principle and analysis of the response surface methodology was based on the Design Expert 8.0.6 software. The 3D stereogram of the response surface intuitively reflects the type of interaction between each factor, and the response value provides the basis for optimized production [23]. A steep slope on the 3D graph surface and densely integrated elliptical contour lines indicate that two factors interact greatly. However, a gentle slope and round contour lines indicate that the interaction between two factors is not significant.

According to Figure $2 \mathrm{a}-\mathrm{f}$, a change in the parameters results in different effects on the yield of PHP. As can be seen from Figure $2 \mathrm{a}, \mathrm{b}$, the influence of $\mathrm{A}$ (raw material to water ratio) and C (temperature) on $\mathrm{Y}$ (the yield) can be determined from the density of the contour lines. When $\mathrm{A}=0.04, \mathrm{C}$ is at the highest point, i.e., $80^{\circ} \mathrm{C}$. As shown in Figure 2c,d, the influence of A and B (extraction time) on $\mathrm{Y}$ can be determined from the elliptical contour. The effect was not significant when $\mathrm{A}=0.04$, and $\mathrm{B}$ reached the highest point, i.e., at $3 \mathrm{~h}$. When the value of $A$ exceeded 0.04 and that of $B$ exceeded $3 \mathrm{~h}$, the polysaccharide extraction rate decreased. From Figure 2e,f, it can be seen that $B$ and $C$ (temperature) versus $\mathrm{Y}$ has a curved 3D stereogram, and relatively sparse contour lines, indicating that its impact is not significant. The yield reaches the highest point when $\mathrm{B}=3 \mathrm{~h}$ and $\mathrm{C}=80^{\circ} \mathrm{C}$. By analysis of the regression equation, the best process for obtaining PHP (calculated based on the yield) must have a raw 
material to water ratio of 0.04 , extraction time of $3 \mathrm{~h}$, and extraction temperature of $80{ }^{\circ} \mathrm{C}$. Under these conditions, the extraction rate of PHP was $20.48 \%$.
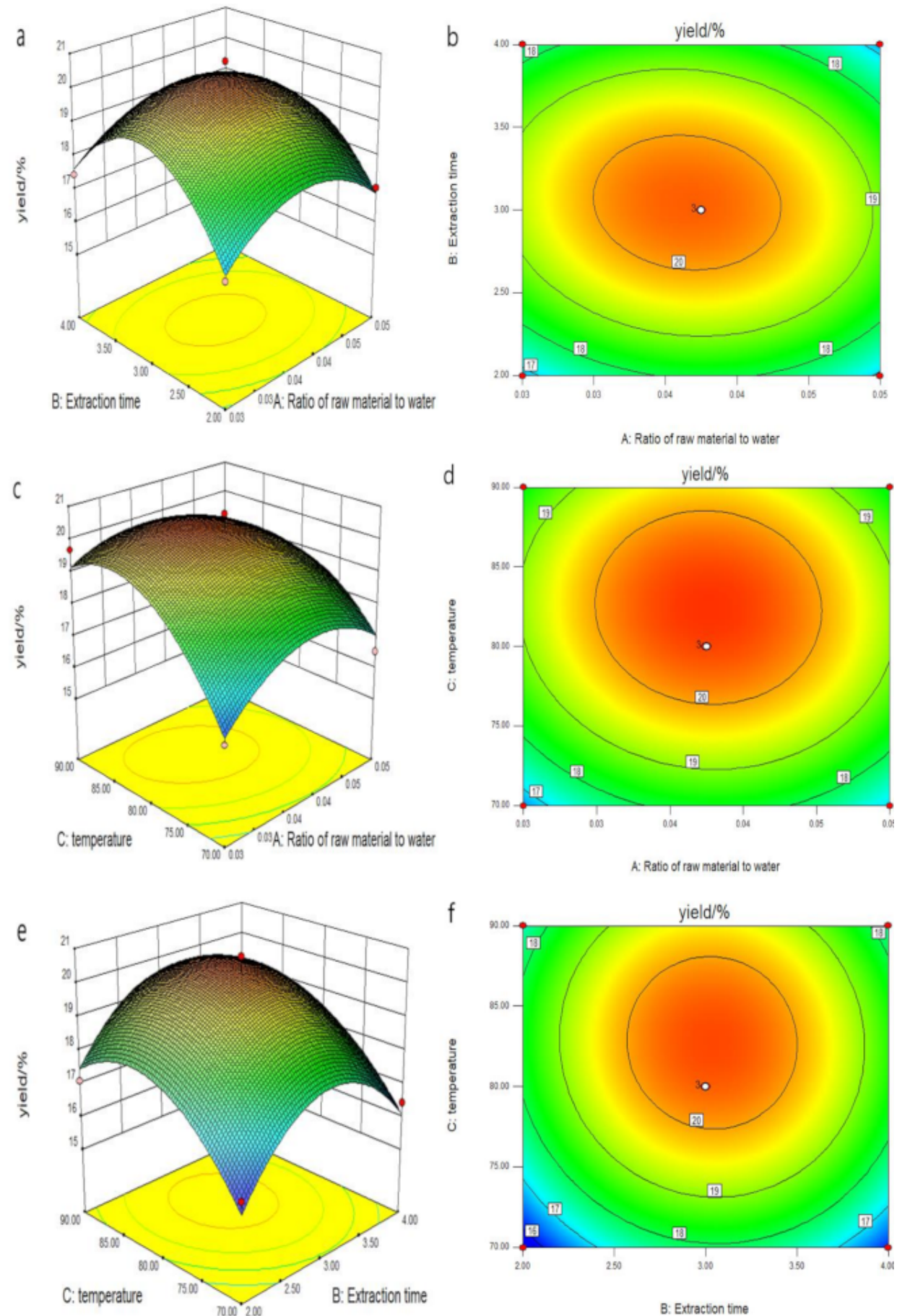

Figure 2. Figures of the variables' mutual effects on the extraction yield. (a,b) Response surface plots of $\mathrm{A}$ and $\mathrm{B},(\mathbf{c}, \mathbf{d})$ response surface plots of $\mathrm{A}$ and $\mathrm{C}$, and $(\mathbf{e}, \mathbf{f})$ response surface plots of $\mathrm{B}$ and $\mathrm{Cs} . \mathrm{A}, \mathrm{B}$, and $C$ represent the ratio of raw material to water, extraction time, and temperature, respectively. 
The above finding was based on the results of the response surface analysis, and it was verified by performing three parallel experiments. The conditions used in the verification experiments were as follows: raw material to water ratio of 0.04 , extraction time of $3 \mathrm{~h}$, and extraction temperature of $80{ }^{\circ} \mathrm{C}$. Under these conditions, the extraction yield obtained was $20.33 \%( \pm 0.15)$, which is similar to the predicted value, thus proving the reliability of the experimental results. The extraction rate of PHPs using traditional water extraction and alcohol precipitation methods is less than 5\% [24,25]. The extraction rate of polysaccharides obtained in this experiment was similar to that reported by Shu-YingXu et al., where the following ultrasonic microwave-assisted extraction conditions were used: extraction time of $30 \mathrm{~min}$, extraction temperature of $80^{\circ} \mathrm{C}$, and liquid-solid ratio of $42 \mathrm{~mL} / \mathrm{g}$ [26]. Therefore, our optimized methodology for the extraction of PHPs were very significant.

\subsection{Physicochemical Properties of PHP}

The physical and chemical characteristics of the PHPs extracted using the optimized experimental variables are presented in Table 3. The protein content was $0.056 \mathrm{~g} / \mathrm{L}$, purity was $85 \%$, and the purity of analytical pure agar was $87.2 \%$. The purity of the PHPs obtained conformed to the food-grade standards. Sulfate content was measured using the $\mathrm{BaCl}_{2}$ turbidimetric method. A single peak was displayed on the liquid phase spectrum, indicating that the polysaccharide was homogeneous. It had an average molecular weight of $6.3 \times 10^{5} \mathrm{Da}$, which corresponds to the molecular weight range of food-grade polysaccharides, which range from $2.0 \times 10^{5} \mathrm{Da}$ to $8.0 \times 10^{5} \mathrm{Da}$. The monosaccharide composition was determined using acid hydrolysis. LC analysis showed that most of the polysaccharides were primarily made up of galactose units, and a small amount of glucose and fucose. As seen in Figure 3a,b, the molar ratio of galactose, glucose, and fucose was 76.2:2.1:1. The differences observed in the chemical composition of the PHPs can be attributed to the discrepancy in the raw materials used.

Table 3. Characteristics of physicochemical properties from PHP.

\begin{tabular}{|c|c|c|c|c|}
\hline $\begin{array}{c}\text { Protein }^{\mathrm{a}} \\
\text { Content } /(\mathrm{g} / \mathrm{L})\end{array}$ & $\begin{array}{l}\text { Polysaccharide } \\
\text { Purity } b / \%\end{array}$ & Sulfate $\mathrm{c} /(\mathrm{mg} / \mathrm{mL})$ & $\begin{array}{c}\text { Molecular } \\
\text { Weight d/Da }\end{array}$ & $\begin{array}{l}\text { Monosaccharide } \\
\text { Composition e } \\
\text { (Molar Ratio) }\end{array}$ \\
\hline & & & & Glucose Galactose Fucose \\
\hline 0.056 & 85 & 2.7 & $6.3 \times 10^{5}$ & 2.176 .21 \\
\hline
\end{tabular}

a: Evaluated by Coomassie Blue; b: Determination of sugar content by phenol-sulfuric acid method; c: Percentage of the weight of Polysaccharide ( $v / v)$; d: Evaluated by HPSEC as a component; e: The monosaccharide composition was detected by LC analysis (molar ratio). 

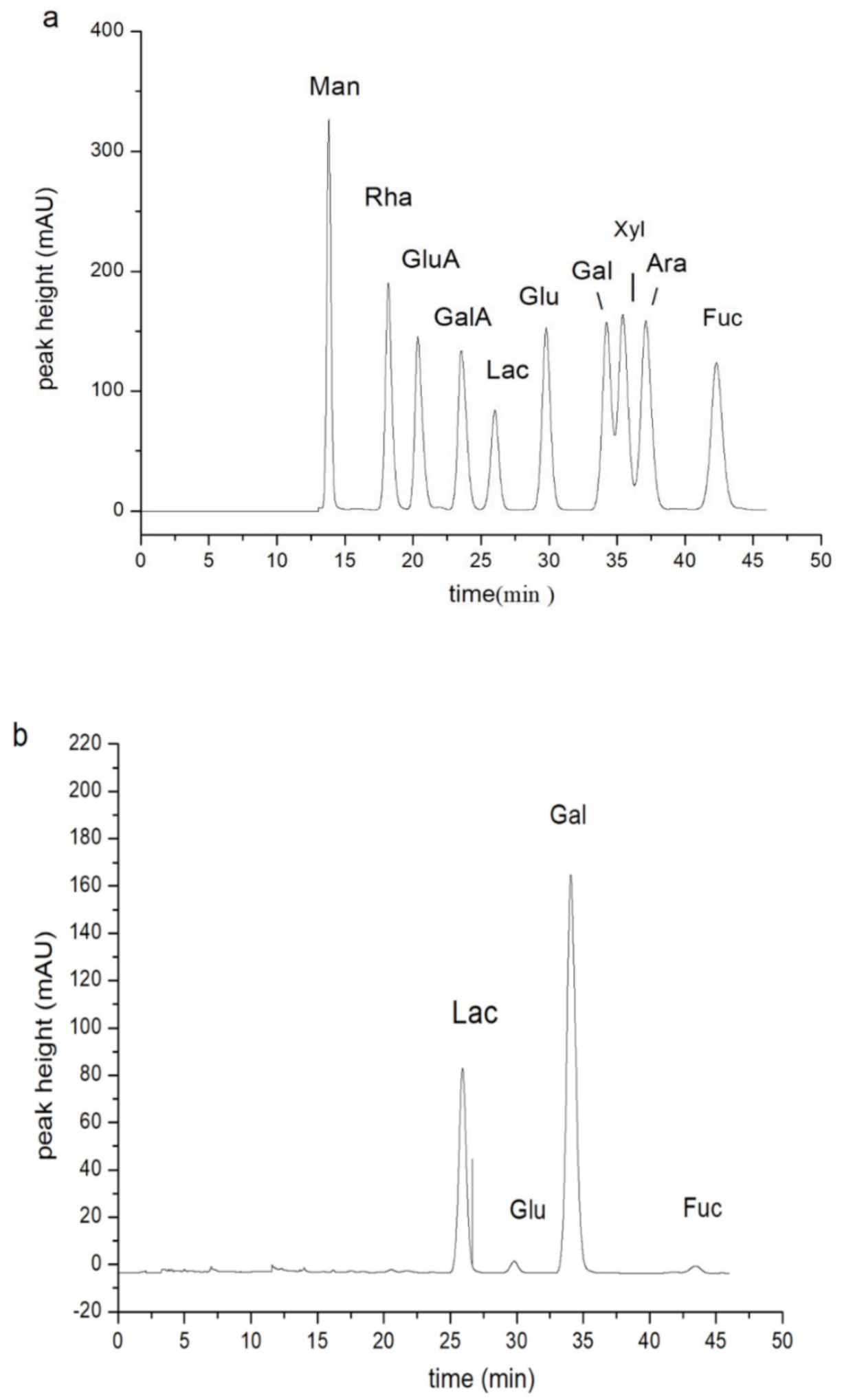

Figure 3. Cont. 


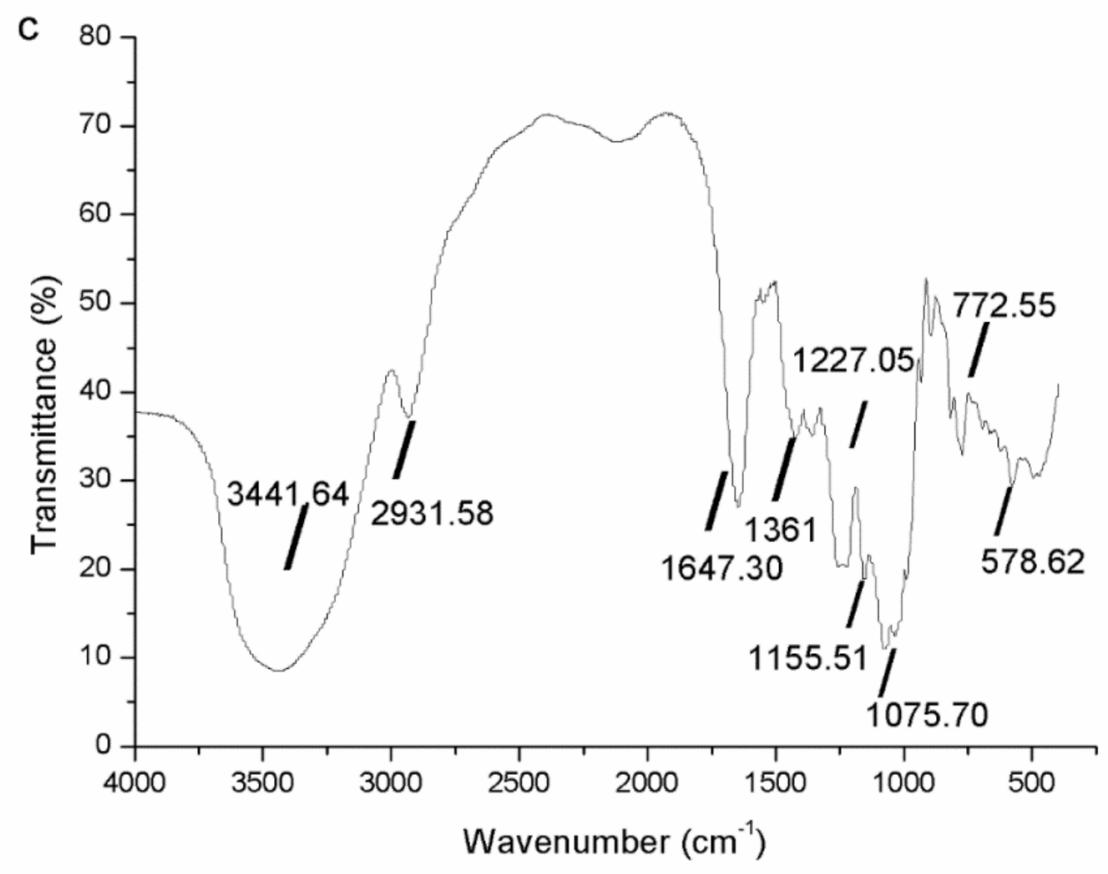

Figure 3. Monosaccharide components of a standard polysaaccharide (a), Monosaccharide components of a porphyra polysaccharide (b), FT-IR spectrum of PHPs (c).

\subsection{FT-IR Spectra of PHPS}

The FTIR spectrum of PHPs is shown in Figure $3 \mathrm{c}: 3441.64 \mathrm{~cm}^{-1}$ was the tensile vibration peak of $\mathrm{O}-\mathrm{H}$, the tensile vibration of the alkane $\mathrm{C}-\mathrm{H}$ bond was observed at $2931.58 \mathrm{~cm}^{-1}$, the peak of polymer bound water was detected at $1647.30 \mathrm{~cm}^{-1}$, and the peak of tensile vibration at $1361 \mathrm{~cm}^{-1}$ was found to be sulfate, which corresponds to the physical and chemical index values detected above. There was an O-S-O tensile vibration peak at $1227.05 \mathrm{~cm}^{-1}$, the tensile vibration of the C-O-C bond was at $1155.51 \mathrm{~cm}^{-1}$, the peak at $1075.70 \mathrm{~cm}^{-1}$ was the position of the tensile vibration of the glycosidic bond, and the $772.55 \mathrm{~cm}^{-1}$ peak was the galactose C4-O-S that was formed by the tensile vibration, and 578.62 was the position of $\mathrm{O}=\mathrm{S}=\mathrm{O}$ (bending) [27]. The spectrum was consistent with the results obtained by Bilal Muhammad Khan et al. [14].

\subsection{Rheological Analysis}

\subsubsection{Effects of Concentration on the Apparent Viscosity of the PHPs Solution}

The flow curve of the PHPs solution in Figure 4a shows that an increase in the shear rate results in a gradual decrease in viscosity, indicating that PHPs display a shear-thinning behavior. This reveals the pseudoplastic fluid properties of PHPs, such as shear thinning behavior, which generally occur in polymer solutions owing to their high molecular weight [28,29]. Additionally, the polysaccharide structure affects the intermolecular force, which in turn affects the apparent viscosity [30]. When the shear rate was higher than $30 \mathrm{~s}^{-1}$, at a certain value, the viscosity increased gradually with an increase in concentration. In addition, the effect of a $0.9 \%(w / w)$ concentrated sugar solution on viscosity was significantly higher than that of other groups, indicating the concentration dependence of the PHPs solution. 

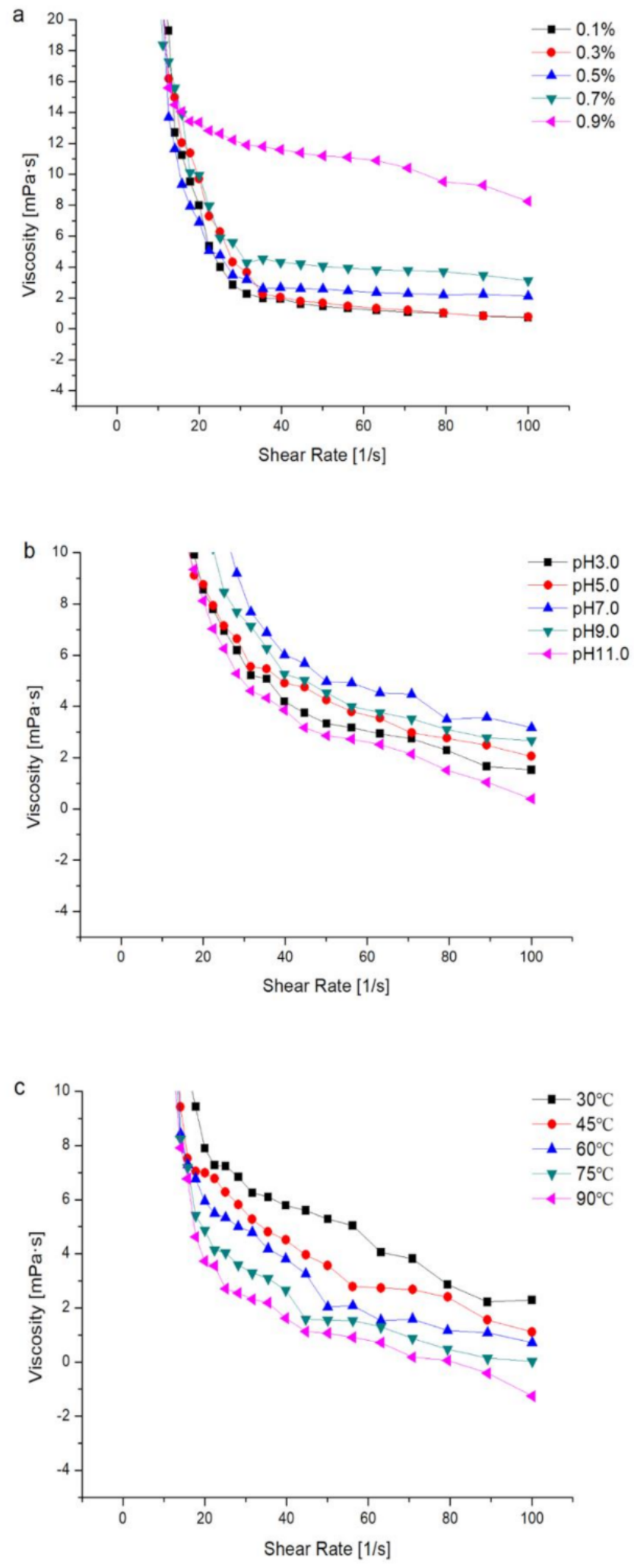

Figure 4. Apparent viscosity of different concentrations of porphyra polysaccharides with increasing shear rate (a). Apparent viscosity of porphyra polysaccharides $(0.5 \%)$ with different $\mathrm{pH}$ values (b). Apparent viscosity of porphyra polysaccharides (0.5\%) with different temperatures (c). 


\subsubsection{Effects of $\mathrm{pH}$ on the Apparent Viscosity of the PHPs Solution}

Figure $4 \mathrm{~b}$ reveals that the PHPs showed shear-thinning behavior in all the $\mathrm{pH}$ values tested: $\mathrm{pH}=3,5,7,9$, and 11 . The viscosity of the polysaccharides decreased with increasing shear rate. The apparent viscosity was higher at $\mathrm{pH} 7$ compared to that at other $\mathrm{pH}$ values. The apparent viscosity at different $\mathrm{pH}$ values showed the following trend: $\mathrm{pH} 7.0>\mathrm{pH} 9.0>\mathrm{pH} 5.0>\mathrm{pH} 3.0>\mathrm{pH} 11.0$. Under both acidic and alkaline conditions, hydrogen bonds are broken, thereby leading to a decrease in the molecular weight of the polysaccharides, a conformational change in the molecular chain [31], and ultimately a decrease in the apparent viscosity.

\subsubsection{Effects of Temperature on the Apparent Viscosity of the PHPs Solution}

The relationship between shear rate and apparent viscosity of the PHPs solution (at $0.5 \%(w / w)$, $\mathrm{pH}=7$, and temperature between $30^{\circ} \mathrm{C}$ and $90^{\circ} \mathrm{C}$ is shown in Figure $4 \mathrm{c}$. As the shear rate increased, the apparent viscosity decreased. At a certain shear rate, the viscosity gradually decreased with increasing temperature. Previous studies have also reported similar findings [32]. Molecular movement is accelerated at high temperatures, leading to a weakening of the connections and interactions. Additionally, PHPs hydrolysis at high temperatures also reduces the viscosity. Owing to thermal movement, the polymer chains also untangle. The temperature characteristic plays an important role in food transportation and baking. This experiment aims to provide a certain basis for the application of PHPs.

\subsection{In Vitro Antioxidant Activity}

The scavenging ability of hydroxyl free radicals is an indicator of their antioxidant activity. Hydroxyl radicals are generally produced in the metabolic process, and they promote oxidative damage. Antioxidants react with hydroxyl radicals and reduce them, thus inhibiting oxidation reactions [33]. $\mathrm{DPPH}^{*}$ (diphenyl bitter hydrazine radical) is a stable free radical. Antioxidants donate electrons or hydrogen ions to $\mathrm{DPPH}^{*}$ free radicals, thus inhibiting the propagation phase of lipid oxidation [34]. Interaction of an antioxidant with $\mathrm{DPPH}^{*}$ changes its color from purple to yellow. The antioxidant ability of a substance is judged by this color change. ABTS*, on the other hand, is a blue water-soluble cationic radical. Antioxidants react with it and cause the solution to fade, and the antioxidant ability is judged based on this discoloration [35].

Dose-dependent clearance activity of polysaccharides was observed using $\mathrm{DPPH}^{*}, \mathrm{OH}^{*}$, and $\mathrm{ABTS}^{*}$ clearance tests. Results showed that the dose dependence was more pronounced at higher concentrations. The clearance activity also depends on the electron transfer ability, molecular weight, water solubility, uronic acid content, glucoside bond, and the type of polysaccharide.

As shown in Figure 5a-c, the lowest $\mathrm{DPPH}^{*}, \mathrm{OH}^{*}$, and $\mathrm{ABTS}^{*}$ clearance effects of $27.10 \%, 13.13 \%$, and $37.99 \%$, respectively, were observed at a concentration of $0.5 \mathrm{mg} / \mathrm{mL}$, while the highest clearance activity, observed at a concentration of $0.9 \mathrm{mg} / \mathrm{mL}$, was $47.58 \%, 37.32 \%$, and $54.39 \%$, respectively. The $\mathrm{DPPH}^{*}, \mathrm{OH}^{*}$, and $\mathrm{ABTS}^{*}$ assays showed that the PHPs extracted using our method showed higher antioxidant activity compared to those extracted by Bilal Muhammad Khan et al. [14]. In the DPPH*, $\mathrm{OH}^{*}$, and ABTS* scavenging activity assays, $\mathrm{Vc}$ showed the highest scavenging activity $(99.5 \%, 98.0 \%$, and $99.0 \%$, respectively). At a concentration of 0.7 and $0.9 \mathrm{mg} / \mathrm{mL}$, the radical scavenging efficiency of ABTS* was greater compared to that of the $\mathrm{OH}^{*}$ and $\mathrm{DPPH}^{*}$ radicals. Collectively, PHPs scavenge the ABTS* free radicals more efficiently, followed by $\mathrm{DPPH}^{*}$, and $\mathrm{OH}^{*}$ free radicals. The antioxidant activity of PHPs was similar to that of comfrey polysaccharides extracted by HongmeiShang et al. [36]. 

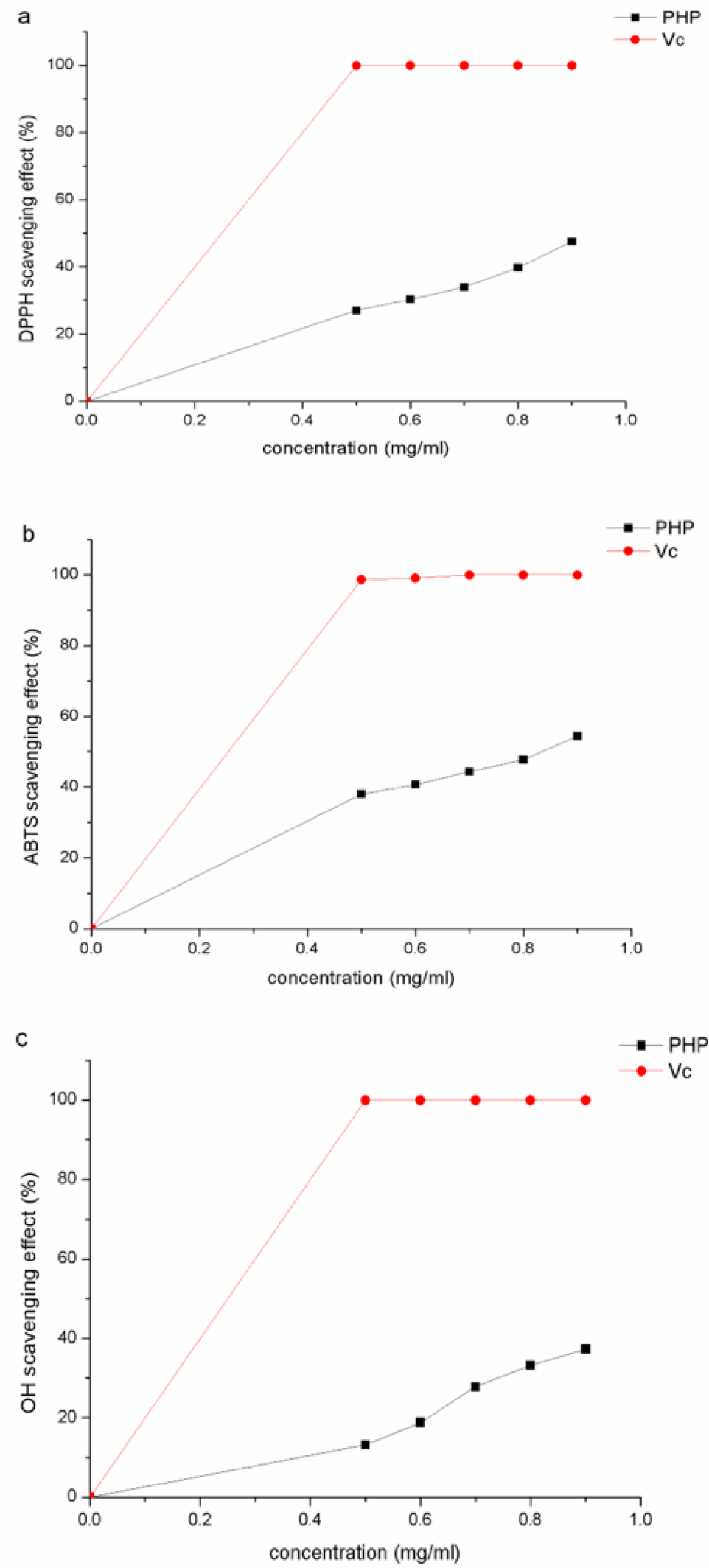

Figure 5. 2,2-diphenyl-1-picrylhydrazyl $\left(\mathrm{DPPH}^{*}\right)$ scavenging effect (a), 2,2'-azino-bis (ABTS*) scavenging effect $(\mathbf{b})$, and hydroxyl radical $\left(\mathrm{OH}^{*}\right)$ scavenging effect $(\mathbf{c})$ of porphyra polysaccharides $($ mean $\pm \mathrm{SD}, n=3)$. 


\subsection{The Digestibility of PHPs by Artificial Human Gastric Juice}

Figure $6 \mathrm{a}, \mathrm{b}$ shows the resistance of PHPs to artificial gastric juice digestion. Taking fructooligosaccharide (FOS) as a reference prebiotic, with the increase of $\mathrm{pH}$, the degree of hydrolysis gradually decreases, showing a higher resistance of PHPs than that of FOS. PHPs digested by artificial gastric juice showed higher acid resistance under the conditions of $\mathrm{pH} 1,2,3,4$, and 5 for $6 \mathrm{~h}$, with values of the degree of hydrolysis of PHPs of $2.13 \%, 1.52 \%, 1.23 \%, 0.72 \%$, and $0.46 \%$, respectively, and values of the degree of hydrolysis of FOS of $2.67 \%, 2.00 \%, 1.35 \%, 1.09 \%$, and $0.98 \%$, respectively. The possible reason for this situation was that glycosidic bonds are more likely to break under acidic conditions; it also shows that PHPs can reach the gastrointestinal tract stably, and can be used as prebiotics for probiotics without being severely degraded. Under normal circumstances, the composition of carbohydrates affects their digestibility, and $\beta$ bonds are more stable than $\alpha$ bonds [17].
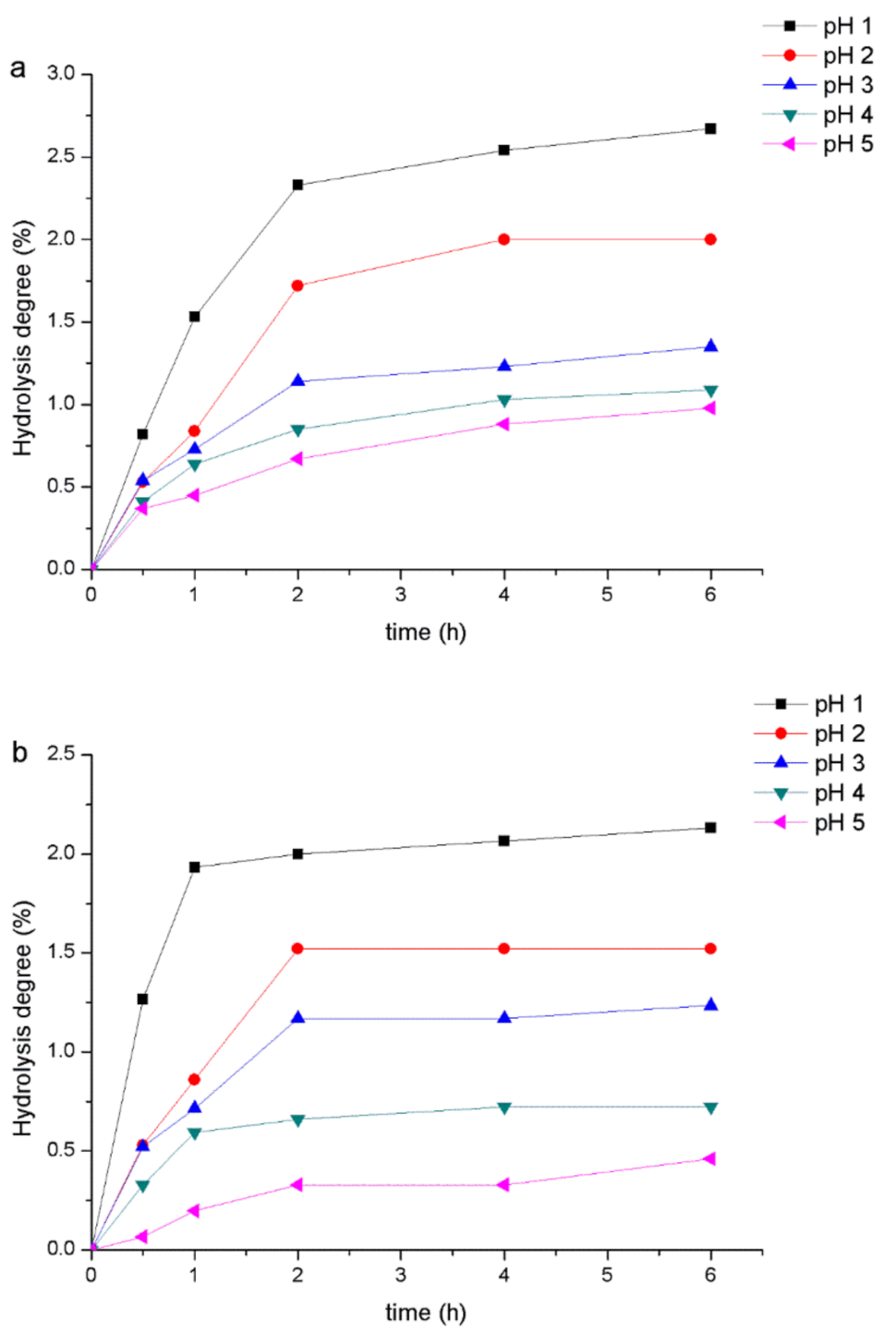

Figure 6. Effect of artificial human gastric juice on hydrolysis of fructooligosaccharide (FOS) (a) and PHPs (b).

\subsection{Analysis of the Digestibility of PHPs by $\alpha$-Amylase}

In the range of $\mathrm{pH} 4-8$, the digestion curve of PHPs resisting alpha amylase is shown in Figure $7 \mathrm{a}, \mathrm{b}$. When the $\mathrm{pH}$ was 7 , there was a higher digestibility, and the order was: $\mathrm{PH}: 7>8>6>5>4$. Moreover, the digestibility did not change after $4 \mathrm{~h}$. When digested for $6 \mathrm{~h}$ under different $\mathrm{pH}$ values (according 
to the above order), the digestion order of PHPs was 5.60\%,4.19\%, 1.90\%, $1.09 \%$, and $0.90 \%$, and the digestibility of FOS was 5.45\%, 5.05\%, 4\%, 2.25\%, and 0.33\%. Compared with FOS, PHPs showed better enzyme resistance and had higher stability to alpha amylase. The resistance to alpha amylase was the primary condition for screening PHPs as a prebiotic, so it can reach the part in the digestive system where the probiotics are used smoothly. These results are similar to those found for Mangifera pajang fibrous pulp and its polysaccharides by S.H. Al-Sheraji et al. [37].
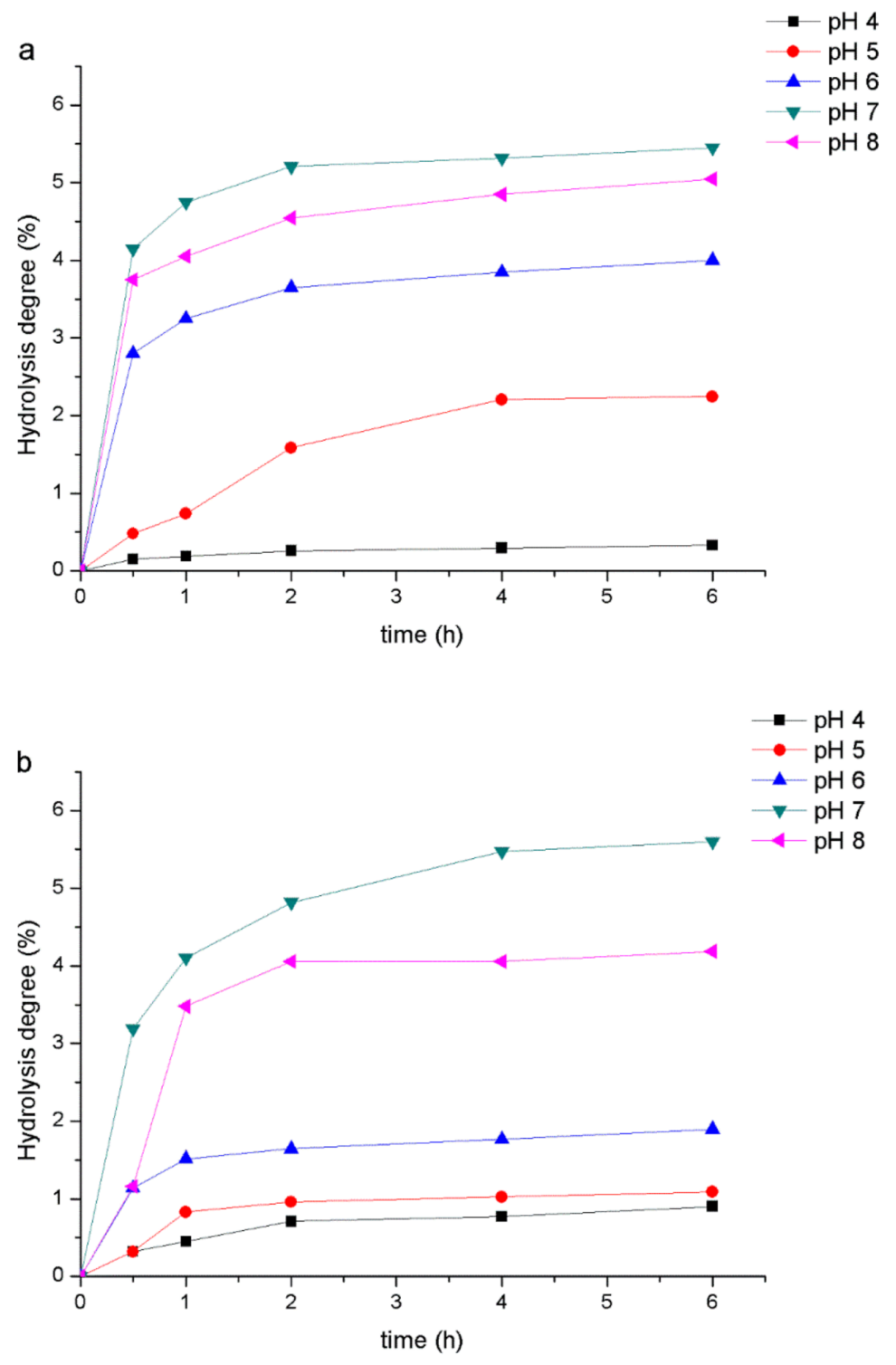

Figure 7. Effect of $\alpha$-amylase on hydrolysis of FOS (a) and PHPs (b).

\section{Materials and Methods}

\subsection{Materials, Reagents, and Equipment}

Haitanensis were cultured near the coast of Fujian province, China.

The following reagents were of analytical grade: 1,1-diphenyl-2-picry-hydrazyl $\left(\mathrm{DPPH}^{*}\right)$, trichloroacetic acid (TCA), ascorbic acid, ABTS (2,2'-Azinobis-(3-ethylbenzthiazoline-6-sulphonate)), and standard sugars. The following equipment was used: a constant temperature bath oscillator (THZ-82A, Suzhou weir laboratory supplies co. LTD.), multi-purpose rotary evaporator (RE-52, shanghai, china), visible spectrophotometer (WFJ2000, Uniko instruments co. LTD.), rheometer 
(MCR101, Austria Anton pa co. LTD.), and FT-IR spectrum (4000-400 $\left.\mathrm{cm}^{-1}\right)$ of the ulvan was recorded using a Magna-IR560 spectrometer (Nicolet Instrument Corp., Madison, WI, USA) with a resolution of $4 \mathrm{~cm}^{-1}$.

\subsection{Extraction of PHPS}

Distilled water was added to dried powder of Porphyra haitanensis to obtain a raw material to water ratio of 1:30 (w/v). Extraction was carried out at $80^{\circ} \mathrm{C}$ for $2 \mathrm{~h}$, followed by centrifugation at $8000 \mathrm{rpm}$ for $10 \mathrm{~min}$. The extract was concentrated by reduced-pressure distillation, and precipitation was performed by adding 3 times the volume of 95\% ethanol and centrifuging at $4800 \mathrm{rpm}$ for $10 \mathrm{~min}$. Subsequently, freeze-drying was carried out to obtain PHPs. The polysaccharide yield was calculated using the following equation:

$$
\text { polysaccharide yield }(\%)=\frac{(\text { weight of polysaccharide extract })}{(\text { weight of each powder sample })} \times 100 \%
$$

\subsection{Experimental Design of RSM}

Based on the results of the single-factor experiment, the extraction time, temperature, and raw material to water ratio were chosen as the process parameters. Three factors and three levels were designed for the Box-Behnken response surface experiment. Three central points were selected, and a total of 15 different test combinations were used to test the factor levels. As shown in Table 4, the mathematical model is as follows [38]:

$$
\mathrm{Y}=\alpha_{0}+\sum_{i=1}^{3} \alpha_{\mathrm{i}} \chi_{\mathrm{i}}+\sum_{i=1}^{3} \partial_{\mathrm{ii}} \chi_{\mathrm{i}}^{2}+\sum_{i<j}^{3} \partial_{i j} \chi_{i} \chi_{j}
$$

where $\mathrm{Y}$ is the predicted response (extraction yield of polysaccharide); $\alpha_{0}, \alpha_{i}, \alpha_{i i}$, and $\alpha_{i j}$ are the regression coefficients for intercept, linear, quadratic, and interaction terms, respectively; and $X_{i}$ and $X_{j}$ are the independent variables.

Table 4. Response surface experiment design factors.

\begin{tabular}{ccccc}
\hline Variable & Symbol & \multicolumn{3}{c}{ Level } \\
\cline { 3 - 5 } & & $\mathbf{- 1}$ & $\mathbf{0}$ & $\mathbf{1}$ \\
\hline $\begin{array}{c}\text { ratios of raw materials to water } \\
(\mathrm{g} / \mathrm{mL})\end{array}$ & $\mathrm{X}_{1}$ & $1: 20$ & $1: 25$ & $1: 30$ \\
$\begin{array}{c}\text { extraction temperature } /{ }^{\circ} \mathrm{C} \\
\text { extraction time/h }\end{array}$ & $\mathrm{X}_{2}$ & 70 & 80 & 90 \\
& $\mathrm{X}_{3}$ & 2 & 3 & 4 \\
\hline
\end{tabular}

\subsection{Physicochemical Properties}

\subsubsection{General Analytical Methods}

The carbohydrate content and purity of the PHPs was determined using the phenol-sulfuric acid method [39], the sulfate content using the barium chloride-gelatin method [40], and the protein content using the Bradford's procedure [41].

\subsubsection{PHPs Composition}

Approximately $4 \mathrm{mg}$ of the polysaccharide sample was hydrolyzed with $2 \mathrm{M}$ trifluoroacetic acid at $105^{\circ} \mathrm{C}$. Trifluoroacetic acid was removed using methanol under reduced pressure $(\geq 0.095 \mathrm{MPa})$, at $50{ }^{\circ} \mathrm{C}$. The hydrolysate was then converted to an acetylated acetonitrile derivative according to the conversion procedure. Derivatization analysis was carried out using high-performance liquid chromatography (HPLC) (Agilent 1100 HPLC, ZORBAX Eclipse XDB-C18 separation column $(4.6 \times 250 \mathrm{~mm}, 5 \mu \mathrm{m}$, Agilent Technologies, Stockport, UK), which was used at an ambient temperature 
of $30^{\circ} \mathrm{C}$. PMP (1-phenyl-3-methyl-5-pyrazolone) derivatives were eluted with a mixture of $0.1 \mathrm{M}$ phosphate buffer ( $\mathrm{pH}$ 6.7) and acetonitrile at a ratio of $83: 17(v / v, \%)$ and a flow rate of $1 \mathrm{~mL} / \mathrm{min}$, which was used to analyze the derivatives at $245 \mathrm{~nm}$. Lactose (internal standard), rhamnose, arabinose, xylose, mannose, fucose, galactose, glucose, glucuronic acid, and galacturonic acid were also converted into acetylated aldehyde nitrile derivatives [42].

\subsubsection{Determination of Molecular Weight}

The average molecular weight was measured using high performance gel permeation chromatography (HPGPC) [43]. A TSK-gel G4000SWXL column and a refractive index detector were used. The mobile phase was a $0.02 \mathrm{M}$ phosphate buffer solution of $\mathrm{pH}$ 6.0. The injection volume was $20 \mu \mathrm{L}$, flow rate was $0.3 \mathrm{~mL} / \mathrm{min}$, and temperature (oven and detector) was $30^{\circ} \mathrm{C}$. Dextran was used to prepare standards of $1 \mathrm{kDa}, 3.65 \mathrm{kDa}, 5 \mathrm{kDa}, 12 \mathrm{kDa}, 21 \mathrm{kDa}, 80 \mathrm{kDa}$, and $150 \mathrm{kDa}$ for the preparation of a standard curve.

\subsubsection{Fourier Transform Infrared Spectroscopy (FT-IR)}

The sample PHPs $(1 \mathrm{mg})$ and $\mathrm{KBr}(100 \mathrm{mg})$ particles were mixed then ground and the tablet press was used to reduce the particle size to less than $5 \mathrm{~mm}$ (thin and transparent small discs) and then the samples were mounted on the Fourier transform infrared spectrometer (FT-IR) for infrared measurements of the spectrum in the range of 4000 to $400 \mathrm{~cm}^{-1}$ [44].

\subsection{Rheological Properties}

\subsubsection{Effect of Concentration on Apparent Viscosity}

PHPs were dissolved in water and their concentrations were adjusted to $0.1 \%, 0.3 \%, 0.5 \%, 0.7 \%$, and $0.9 \%$. A MCR101 rheometer with a pp50 rotor was used. The temperature was set at $25^{\circ} \mathrm{C}$ and the shear rate was $10-100 \mathrm{~s}^{-1}$.

\subsubsection{Effect of $\mathrm{pH}$ on Apparent Viscosity}

The $\mathrm{pH}$ of the PHPs solutions $(0.5 \%(w / v))$ was adjusted using $0.03 \mathrm{M} \mathrm{HCl}$ and $0.03 \mathrm{M} \mathrm{NaOH}$ to obtain $\mathrm{pH}$ values of 3.0, 5.0, 7.0, 9.0, and 11.0. The rheometer parameters described in Section 3.5.1 were used for measurement.

\subsubsection{Effect of Temperature on Apparent Viscosity}

Polysaccharide solutions with a concentration of $0.5 \%(w / v)$ were set at temperatures of $30{ }^{\circ} \mathrm{C}$, $45^{\circ} \mathrm{C}, 60^{\circ} \mathrm{C}, 75^{\circ} \mathrm{C}$, and $90^{\circ} \mathrm{C}$. The samples were prepared as described in Section 3.5.1.

\subsection{In Vitro Antioxidant Activity}

\subsubsection{DPPH* Radical Scavenging Effect}

Approximately $2 \mathrm{~mL}$ of DPPH* solution $\left(2 \times 10^{-4} \mathrm{M}\right.$, configured with methanol) and $2 \mathrm{~mL}$ of polysaccharide solution or ascorbic acid $(\mathrm{Vc})$ solution of different concentrations were added to a test tube. The reaction was shielded from light, and the tube was incubated at room temperature for $30 \mathrm{~min}$. The absorbance of the samples was measured at a wavelength of $517 \mathrm{~nm}$. The original solvent was used as a blank, and Vc was used as the positive control. The $\mathrm{DPPH}^{*}$ radical scavenging effect was calculated using the following equation [45]:

$$
\text { Scavenging effect }(\%)=\left[1-\left(\mathrm{A}_{\mathrm{i}}-\mathrm{A}_{\mathrm{i} 0}\right) / \mathrm{A}_{0}\right] \times 100 \%
$$

where $A_{i}$ is $2 \mathrm{~mL} \mathrm{DPPH}^{*}+2 \mathrm{~mL}$ sample solution; $\mathrm{A}_{\mathrm{i} 0}$ is $2 \mathrm{~mL}$ sample solution $+2 \mathrm{~mL}$ solvent; and $\mathrm{A}_{0}$ is $2 \mathrm{~mL} \mathrm{DPPH}^{*}+2 \mathrm{~mL}$ solvent. 


\subsubsection{Hydroxyl Free Radical (HO) Scavenging Effect}

Around $1 \mathrm{~mL}$ of $8 \mathrm{mM} \mathrm{H}_{2} \mathrm{O}_{2}$ solution, $9 \mathrm{mM} \mathrm{FeSO}_{4}$ solution, and $1 \mathrm{~mL}$ of $9 \mathrm{mM}$ salicylic acid-ethanol solution were added to each aliquot of $1 \mathrm{~mL}$ polysaccharide solution of different concentrations. Following incubation at $37^{\circ} \mathrm{C}$ for $30 \mathrm{~min}$, the absorbance was measured at a wavelength of $510 \mathrm{~nm}$ [13]. Vc was used as the positive control. The hydroxyl free radical scavenging effect was calculated using the following equation:

$$
\text { Scavenging effect }(\%)=\left[\mathrm{A}_{0}-\left(\mathrm{A}_{\mathrm{i}}-\mathrm{A}_{\mathrm{i} 0}\right)\right] / \mathrm{A}_{0} \times 100 \%
$$

where $A_{0}$ is a blank control measured by using distilled water instead of a polysaccharide solution, $A_{i}$ is the sample absorption value, and $\mathrm{A}_{\mathrm{i} 0}$ is the polysaccharide background absorption value.

\subsubsection{ABTS* Radical Scavenging Effect}

The ABTS* working solution was obtained by mixing equal volumes of $7.4 \mathrm{mM}$ ABTS* and $2.6 \mathrm{mM}$ potassium persulfate solution and placing it in the dark for 12 to $16 \mathrm{~h}$. The mixture was then diluted using phosphate buffer solution ( $\mathrm{pH} 7.4$ ) until the absorbance at $730 \mathrm{~nm}$ was $0.70 \pm 0.02$ [46].

Subsequently, $2.4 \mathrm{~mL}$ of ABTS* working solution and $0.6 \mathrm{~mL}$ of the sample solution were mixed evenly, and placed at room temperature for $6 \mathrm{~min}$. The absorbance was measured at $730 \mathrm{~nm}$, and Vc was used as the positive control. The ABTS radical scavenging effect was calculated using the following equation:

$$
\text { Scavenging effect }(\%)=\left[1-\left(\mathrm{A}_{\mathrm{i}}-\mathrm{A}_{\mathrm{i} 0}\right) / \mathrm{A}_{0}\right] \times 100 \%
$$

where $A_{i}$ is $2.4 \mathrm{~mL}$ ABTS* $+0.6 \mathrm{~mL}$ sample solution; $A_{i 0}$ is $2.4 \mathrm{~mL}$ sample solution $+0.6 \mathrm{~mL}$ solvent; and $\mathrm{A}_{0}$ is $2.4 \mathrm{~mL} \mathrm{ABTS*}+0.6 \mathrm{~mL}$ solvent.

\subsection{Analysis of the Digestibility of PHPs by Artificial Human Gastric Juice}

PHPs sample and positive controls by artificial human gastric juice were first identified by the following methods, described previously by al-Sheraji et al. (2012). Artificial human gastric juice was prepared by dissolving $0.2 \mathrm{~g} \mathrm{KCl}, 8.0 \mathrm{~g} \mathrm{NaCl}, 14.35 \mathrm{~g} \mathrm{NaH}_{2} \mathrm{PO}_{4}, 8.25 \mathrm{~g} \mathrm{Na}_{2} \mathrm{HPO}_{4} \cdot 2 \mathrm{H}_{2} \mathrm{O}$, $0.18 \mathrm{~g} \mathrm{MgCl}_{2} \cdot 6 \mathrm{H}_{2} \mathrm{O}$, and $0.1 \mathrm{~g} \mathrm{CaCl}_{2} \cdot 2 \mathrm{H}_{2} \mathrm{O}$ in $1000 \mathrm{~mL}$ deionized water and using $5 \mathrm{M} \mathrm{HCl}$ solution to adjust the $\mathrm{pH}$ to $1,2,3,4$, and 5 . A mixture of $5.0 \mathrm{~mL}$ PHPs or FOS solution $(10 \mathrm{mg} / \mathrm{mL})$ and $5.0 \mathrm{~mL}$ artificial gastric juice (at each $\mathrm{pH}$ value) was prepared and incubated in a water bath $\left(37 \pm 1^{\circ} \mathrm{C}\right)$ for $6 \mathrm{~h}$. At $0,0.5,1,2,4$, and $6 \mathrm{~h}$ of digestion, $2.0 \mathrm{~mL}$ of the reaction mixture was taken out and the reducing sugar and total sugar contents were estimated by the 3, 5-dinitrosalicylic acid (DNS) method [47] and phenol-sulfuric acid method [39]. The hydrolysis degree of the sample was calculated according to the following formula:

$$
\text { degree of hydrolysis }(\%)=\frac{\text { reducing sugar released }}{\text { total sugar }- \text { initial reducing sugar }} \times 100
$$

The reducing sugar released was the difference between the reducing sugar after hydrolysis and the initial reducing sugar.

\subsection{Analysis of the Digestibility of PHPs by $\alpha$-Amylase}

According to the authors of [48] and in line with other methods to determine the resistance of the PHPs sample to alpha amylase, the PHPs sample and FOS (positive control) were dissolved in sodium phosphate buffer solution $(20 \mathrm{mM})$, received $10 \mathrm{mg} / \mathrm{mL}$ of the sample solution, $20 \mathrm{mg}$ of alpha amylase, and $500 \mathrm{~mL}$ sodium phosphate buffer $(20 \mathrm{mM})$ mixed in sodium chloride $(6.7 \mathrm{mM})$. They were eventually $\mathrm{pH}$ adjusted to $\mathrm{pH}$ values of $4,5,6,7$, and 8 to give ( $2 \mathrm{unit} / \mathrm{mL})$ alpha amylase solutions with different $\mathrm{pH}$ values. A mixture of PHPs solution $(10 \mathrm{mg} / \mathrm{mL}$, soluble in sodium phosphate buffer) and amylase solution (at each $\mathrm{pH}$ ) with a volume ratio of 1:1 was prepared and the solution was incubated 
in a water bath $\left(37 \pm 1^{\circ} \mathrm{C}\right)$ for $6 \mathrm{~h}$. Samples $(1 \mathrm{~mL})$ were collected from the mixture for $0,0.5,1,2,4$, and $6 \mathrm{~h}$, and the hydrolysis degree of PHPs samples was determined by calculating the reducing sugar and total sugar content.

\subsection{Statistical Analysis}

All experiments were repeated thrice $(n=3)$ and the data were expressed as mean \pm standard deviation. The Design-Expert software (version 8.0.6, Stat-Ease, Inc., Minneapolis, MN, USA) was used for the design as well as data analysis of RSM. The SPSS 18.0 software (SPSS Inc., Chicago, IL, USA) was used for the calculation of statistical significance, which was assessed using one way analysis of variance (ANOVA) followed by Duncan's test. $p<0.05$ was considered to be statistically significant.

\section{Conclusions}

Optimum conditions for the extraction of PHPs (in terms of yield) were obtained using the Box-Behnken response surface design: the raw material to water ratio was 0.04 , time was $3 \mathrm{~h}$, and temperature was $80^{\circ} \mathrm{C}$. Under these conditions, the extraction rate of PHPs was $20.33 \%( \pm 0.15)$. Therefore, this extraction method has little effect on the structure and function of polysaccharides and high yield. The extracted PHPs primarily consisted of three types of monosaccharides, namely galactose, glucose, and fucose, in the molar ratio 76.2:2.1:1. The average molecular weight of the PHPs was $6.3 \times 10^{5} \mathrm{Da}$. The molecular weight affects the antioxidant activity of the polysaccharides to a certain extent. Free radical scavenging analysis showed that the relatively strong antioxidant activity of PHPs in vitro functioned in a concentration-dependent manner. PHPs showed higher scavenging activity on ABTS* compared to that on $\mathrm{OH}^{*}$ and $\mathrm{DPPH}^{*}$. Rheological experiments showed that PHPs were "non-Newtonian fluids" with a shear-thinning behavior. In the experiment of simulating gastric juice and alpha amylase in vitro, PHPs had better resistance than FOS, and it is predicted that polysaccharides have good prebiotic activity. Following purification, PHPs can be used as thickeners in the food processing industry. They also provide a certain basis for food transportation and baking. Owing to the good antioxidant activity of PHPs, they are potential agents for use in the pharmaceutical and cosmetic industries.

Author Contributions: Data curation, M.D., C.Z., and Y.J.; Formal analysis, M.D. and C.W.; Funding acquisition, C.Z.; Investigation, Q.Y.; Methodology, Y.J.; Project administration, X.J.; Resources, C.Z. and Q.Y.; Supervision, Y.J.; Writing-original draft, M.D.; Writing-review and editing, M.D. All authors have read and agreed to the published version of the manuscript.

Funding: This work was funded by the National Key Research and Development Project of China (2019YFD0901800).

Conflicts of Interest: The authors declare that they have no conflict of interest. All authors confirmed the manuscript authorship and agreed to submit it for peer review.

\section{References}

1. Liu, D.; Keesing, J.K.; Dong, Z.; Zhen, Y.; Di, B.; Shi, Y.; Fearns, P.; Shi, P. Recurrence of the world's largest green-tide in 2009 in Yellow Sea, China: Porphyra yezoensis aquaculture rafts confirmed as nursery for macroalgal blooms. Mar. Pollut. Bull. 2010, 60, 1423-1432. [CrossRef] [PubMed]

2. Zhang, Q.; Li, N.; Liu, X.; Zhao, Z.; Li, Z.; Xu, Z. The structure of a sulfated galactan from Porphyra haitanensis and its in vivo antioxidant activity. Carbohydr. Res. 2004, 339, 105-111. [CrossRef] [PubMed]

3. Cao, J.; Wang, J.; Wang, S.; Xu, X. Porphyra Species: A Mini-Review of Its Pharmacological and Nutritional Properties. J. Med. Food 2016, 19, 111-119. [CrossRef] [PubMed]

4. Wang, W.; Zhang, P.; Hao, C.; Zhang, X.-E.; Cui, Z.-Q.; Guan, H.-S. In vitro inhibitory effect of carrageenan oligosaccharide on influenza A H1N1 virus. Antivir. Res. 2011, 92, 237-246. [CrossRef] [PubMed]

5. Yuan, H.; Zhang, W.; Li, X.; Lü, X.; Li, N.; Gao, X.; Song, J. Preparation and in vitro antioxidant activity of $\mathrm{k}$-carrageenan oligosaccharides and their oversulfated, acetylated, and phosphorylated derivatives. Carbohydr. Res. 2005, 340, 685-692. [CrossRef] [PubMed] 
6. Zhang, Z.; Zhang, Q.; Wang, J.; Zhang, H.; Niu, X.; Li, P. Preparation of the different derivatives of the low-molecular-weight porphyran from Porphyra haitanensis and their antioxidant activities in vitro. Int. J. Biol. Macromol. 2009, 45, 22-26. [CrossRef] [PubMed]

7. Weiyun, Z.; Jianfeng, Z.; Hao, C.; Lijun, L.; Yayi, H. Effects of a polysaccharide from Porphyra yezoensis on Murin Immunocytes and Human Leukemia K562 Cells. Life Sci. Res. 2002, 6, 167-170.

8. Qian, L.; Zhou, Y.; Ma, J.-X. Hypolipidemic effect of the polysaccharides from Porphyra yezoensis. Int. J. Biol. Macromol. 2014, 68, 48-49. [CrossRef]

9. Meitian, X.; Junling, Y.; Haiying, L.; Fengxiang, T.; Chun, M.; Xianai, S.; Yanghao, G. Extraction of Porphyra haitanensis polysaccharides and its anti-influenza virus activity. J. Fuzhou Univ. 2003, 31, 631-635.

10. Zhang, Z.; Zhang, Q.; Wang, J.; Song, H.; Zhang, H.; Niu, X. Chemical modification and influence of function groups on the in vitro-antioxidant activities of porphyran from Porphyra haitanensis. Carbohydr. Polym. 2010, 79, 290-295. [CrossRef]

11. Zhang, Q.; Li, N.; Zhou, G.; Lu, X.; Xu, Z.; Li, Z. In vivo antioxidant activity of polysaccharide fraction from Porphyra haitanesis (Rhodephyta) in aging mice. Pharmacol. Res. 2003, 48, 151-155. [CrossRef]

12. Zhao, T.; Zhang, Q.; Qi, H.; Zhang, H.; Niu, X.; Xu, Z.; Li, Z. Degradation of porphyran from Porphyra haitanensis and the antioxidant activities of the degraded porphyrans with different molecular weight. Int. J. Biol. Macromol. 2006, 38, 45-50. [CrossRef] [PubMed]

13. Gong, G.; Zhao, J.; Wang, C.; Wei, M.; Dang, T.; Deng, Y.; Sun, J.; Song, S.; Huang, L.; Wang, Z. Structural characterization and antioxidant activities of the degradation products from Porphyra haitanensis polysaccharides. Process. Biochem. 2018, 74, 185-193. [CrossRef]

14. Khan, B.M.; Qiu, H.-M.; Xu, S.-Y.; Liu, Y.; Cheong, K.-L. Physicochemical characterization and antioxidant activity of sulphated polysaccharides derived from Porphyra haitanensis. Int. J. Biol. Macromol. 2020, 145, 1155-1161. [CrossRef]

15. Sharma, N.; Srivastava, P.; Sharma, A.; Nishad, D.K.; Karwasra, R.; Khanna, K.; Kakkar, D.; Bhatnagar, A. Potential applications of Abelmoschus moschatus polysaccharide as colon release tablets-Rheology and gamma scintigraphic study. J. Drug Deliv. Sci. Technol. 2020, 57, 101632. [CrossRef]

16. Covis, R.; Desbrières, J.; Marié, E.; Durand, A. Dilational rheology of air/water interfaces covered by nonionic amphiphilic polysaccharides. Correlation with stability of oil-in-water emulsions. Colloids Surf. A: Physicochem. Eng. Asp. 2014, 441, 312-318. [CrossRef]

17. Wang, X.; Huang, M.; Yang, F.; Sun, H.; Zhou, X.; Guo, Y.; Zhang, M. Rapeseed polysaccharides as prebiotics on growth and acidifying activity of probiotics in vitro. Carbohydr. Polym. 2015, 125, 232-240. [CrossRef]

18. Mateos-Aparicio, I.; Martera, G.; Goni, I.; Villanueva-Suárez, M.J.; Cuenca, A.R. Chemical structure and molecular weight influence the in vitro fermentability of polysaccharide extracts from the edible seaweeds Himathalia elongata and Gigartina pistillata. Food Hydrocoll. 2018, 83, 348-354. [CrossRef]

19. Braga, M.E.; Moreschi, S.; Meireles, M.A.A. Effects of supercritical fluid extraction on Curcuma longa L. and Zingiber officinale R. starches. Carbohydr. Polym. 2006, 63, 340-346. [CrossRef]

20. Chen, C.; You, L.-J.; Abbasi, A.M.; Fu, X.; Liu, R.H. Optimization for ultrasound extraction of polysaccharides from mulberry fruits with antioxidant and hyperglycemic activity in vitro. Carbohydr. Polym. 2015, 130, 122-132. [CrossRef]

21. Wang, C.; Wang, Y.; Zhang, J.; Wang, Z. Optimization for the extraction of polysaccharides from Gentiana scabra Bunge and their antioxidant in vitro and anti-tumor activity in vivo. J. Taiwan Inst. Chem. Eng. 2014, 45, 1126-1132. [CrossRef]

22. Maran, J.P.; Sivakumar, V.; Thirugnanasambandham, K.; Sridhar, R. Artificial neural network and response surface methodology modeling in mass transfer parameters predictions during osmotic dehydration of Carica papaya L. Alex. Eng. J. 2013, 52, 507-516. [CrossRef]

23. Xie, J.-H.; Shen, M.-Y.; Xie, M.-Y.; Nie, S.-P.; Chen, Y.; Li, C.; Huang, D.-F.; Wang, Y.-X. Ultrasonic-assisted extraction, antimicrobial and antioxidant activities of Cyclocarya paliurus (Batal.) Iljinskaja polysaccharides. Carbohydr. Polym. 2012, 89, 177-184. [CrossRef] [PubMed]

24. Chen, Y.-Y.; Xue, Y.-T. Optimization of microwave assisted extraction, chemical characterization and antitumor activities of polysaccharides from porphyra haitanensis. Carbohydr. Polym. 2019, 206, 179-186. [CrossRef] [PubMed]

25. Xu, S.-Y.; Aweya, J.J.; Li, N.; Deng, R.-Y.; Chen, W.-Y.; Tang, J.; Cheong, K.-L. Microbial catabolism of Porphyra haitanensis polysaccharides by human gut microbiota. Food Chem. 2019, 289, 177-186. [CrossRef] [PubMed] 
26. Xu, S.-Y.; Chen, X.-Q.; Liu, Y.; Cheong, K.-L. Ultrasonic/microwave-assisted extraction, simulated digestion, and fermentation in vitro by human intestinal flora of polysaccharides from Porphyra haitanensis. Int. J. Biol. Macromol. 2020, 152, 748-756. [CrossRef] [PubMed]

27. Şen, M.; Erboz, E.N. Determination of critical gelation conditions of $\mathrm{k}$-carrageenan by viscosimetric and FT-IR analyses. Food Res. Int. 2010, 43, 1361-1364. [CrossRef]

28. Wang, B.; Zhang, W.; Bai, X.; Li, C.; Xiang, D. Rheological and physicochemical properties of polysaccharides extracted from stems of Dendrobium officinale. Food Hydrocoll. 2020, 103, 105706. [CrossRef]

29. Niu, Y.; Li, N.; Xia, Q.; Hou, Y.; Xu, G. Comparisons of three modifications on structural, rheological and functional properties of soluble dietary fibers from tomato peels. LWT 2018, 88, 56-63. [CrossRef]

30. Wang, J.; Ma, Z.; Zhang, L.; Fang, Y.; Jiang, F.; Phillips, G.O. Structure and chain conformation of water-soluble heteropolysaccharides from Ganoderma lucidum. Carbohydr. Polym. 2011, 86, 844-851. [CrossRef]

31. Ji, Y.-H.; Liao, A.-M.; Huang, J.-H.; Thakur, K.; Li, X.-L.; Hu, F.; Wei, Z.-J. The rheological properties and emulsifying behavior of polysaccharides sequentially extracted from Amana edulis. Int. J. Biol. Macromol. 2019, 137, 160-168. [CrossRef] [PubMed]

32. Xu, G.-Y.; Liao, A.-M.; Huang, J.-H.; Zhang, J.-G.; Thakur, K.; Wei, Z.-J. The rheological properties of differentially extracted polysaccharides from potatoes peels. Int. J. Biol. Macromol. 2019, 137, 1-7. [CrossRef]

33. Zhang, Z.; Zhang, Q.; Wang, J.; Shi, X.; Song, H.; Zhang, J. In vitro antioxidant activities of acetylated, phosphorylated and benzoylated derivatives of porphyran extracted from Porphyra haitanensis. Carbohydr. Polym. 2009, 78, 449-453. [CrossRef]

34. Zhang, C.-H.; Yu, Y.; Liang, Y.-Z.; Chen, X. Purification, partial characterization and antioxidant activity of polysaccharides from Glycyrrhiza uralensis. Int. J. Biol. Macromol. 2015, 79, 681-686. [CrossRef] [PubMed]

35. Mirzadeh, M.; Arianejad, M.R.; Khedmat, L. Antioxidant, antiradical, and antimicrobial activities of polysaccharides obtained by microwave-assisted extraction method: A review. Carbohydr. Polym. 2020, 229, 115421. [CrossRef] [PubMed]

36. Shang, H.; Zhao, J.; Guo, Y.; Zhang, H.; Duan, M.; Wu, H. Extraction, purification, emulsifying property, hypoglycemic activity, and antioxidant activity of polysaccharides from comfrey. Ind. Crop. Prod. 2020, 146, 112183. [CrossRef]

37. Al-Sheraji, S.H.; Ismail, A.; Manap, M.Y.; Mustafa, S.; Yusof, R.M.; Hassan, F.A. Fermentation and non-digestibility of Mangifera pajang fibrous pulp and its polysaccharides. J. Funct. Foods 2012, 4, 933-940. [CrossRef]

38. Wang, Y.; Jia, J.; Ren, X.; Li, B.; Zhang, Q. Extraction, preliminary characterization and in vitro antioxidant activity of polysaccharides from Oudemansiella radicata mushroom. Int. J. Biol. Macromol. 2018, 120, 1760-1769. [CrossRef]

39. Dubois, M.; Gilles, K.A.; Hamilton, J.K.; Rebers, P.A.; Smith, F. Colorimetric Method for Determination of Sugars and Related Substances. Anal. Chem. 1956, 28, 350-356. [CrossRef]

40. Kawai, Y.; Seno, N.; Anno, K. A modified method for chondrosulfatase assay. Anal. Biochem. 1969, 32, $314-321$. [CrossRef]

41. Bradford, M.M. A rapid and sensitive method for the quantitation of microgram quantities of protein utilizing the principle of protein-Dye binding. Anal. Biochem. 1976, 72, 248-254. [CrossRef]

42. Zhang, J.; Zhang, Q.; Wang, J.; Shi, X.; Zhang, Z. Analysis of the monosaccharide composition of fucoidan by precolumn derivation HPLC. Chin. J. Oceanol. Limnol. 2009, 27, 578-582. [CrossRef]

43. Himmel, M.E.; Squire, P.G. High-performance size exclusion chromatography of sea worm chlorocruorin and other large proteins, viruses and polysaccharides on a TSK G5000 PW preparative column. J. Chromatogr. A 1981, 210, 443-452. [CrossRef]

44. Xu, S.-Y.; Liu, J.-P.; Huang, X.; Du, L.-P.; Shi, F.-L.; Dong, R.; Huang, X.-T.; Zheng, K.; Liu, Y.; Cheong, K.-L. Ultrasonic-microwave assisted extraction, characterization and biological activity of pectin from jackfruit peel. LWT 2018, 90, 577-582. [CrossRef]

45. Yamaguchi, T.; Takamura, H.; Matoba, T.; Terao, J. HPLC Method for Evaluation of the Free Radical-scavenging Activity of Foods by Using 1,1-Diphenyl-2-picrylhydrazyl. Biosci. Biotechnol. Biochem. 1998, 62, 1201-1204. [CrossRef]

46. Rozi, P.; Abuduwaili, A.; Mutailifu, P.; Gao, Y.; Rakhmanberdieva, R.; Aisa, H.A.; Yili, A. Sequential extraction, characterization and antioxidant activity of polysaccharides from Fritillaria pallidiflora Schrenk. Int. J. Biol. Macromol. 2019, 131, 97-106. [CrossRef] 
47. Saqib, A.A.N.; Whitney, P.J. Differential behaviour of the dinitrosalicylic acid (DNS) reagent towards monoand di-saccharide sugars. Biomass-Bioenergy 2011, 35, 4748-4750. [CrossRef]

48. Wichienchot, S.; Jatupornpipat, M.; Rastall, R. Oligosaccharides of pitaya (dragon fruit) flesh and their prebiotic properties. Food Chem. 2010, 120, 850-857. [CrossRef]

Publisher's Note: MDPI stays neutral with regard to jurisdictional claims in published maps and institutional affiliations.

(C) 2020 by the authors. Licensee MDPI, Basel, Switzerland. This article is an open access article distributed under the terms and conditions of the Creative Commons Attribution (CC BY) license (http://creativecommons.org/licenses/by/4.0/). 